\title{
correspondence
}

\section{Selling the Sun}

SIR,-Since I am part owner of what I believe to be the only completely privately built and financed house in Britain to incorporate solar central as well as water heating, I would like to present some information which could have a bearing on your editorial (May 20 , page 177 ).

The installation was designed by Stephen Szokolay, who also designed the Milton Keynes House. Central heating is by circulation of warm water through pipes in the floor, to maintain a background warmth; water heating is by a heat exchanger in a conventional domestic tank.

In the absence of a systematic monitoring programme-it being difficult to get any financial support for what most people clearly thought was either a con-trick or the vapourings of a diseased mind-I have estimated that of the approximately $17,000 \mathrm{kWh}$ annual heating demand predicted by the designer, the sun has supplied in the order of $9,000 \mathrm{kWh}$, possibly more, but certainly not much less, during the first year of operation.

The house is insulated to aboveaverage standards, and the underfloor pipe system ensures that in summer months on very hot days, excess hot water can be pumped through the floor, which thus acts both as heat sink and heat store. If the heat decay curve for the floor slab is flat enough, some residue of surplus summer heat could possibly be retained into autumn.

Electrical immersion heaters and a wood stove are used as back-up heating for sunless days. During last winter there were periods of up to 2 weeks when the solar input could only be described as negligible. In the absence of a completely new style of house design, I cannot see how the need for a back-up system is to be avoided.

Which brings us to costs. First, energy costs: my rather crude calculations lead me to conclude that the energy cost of materials over and above what would be required for a conventional fossil-fuel piped heating system (that is, collector panels and glazing, storage tank, anti-freeze, piping, pumps, switches) is in the order of $20-25,000 \mathrm{kWh}$. The system needs to run trouble-free for at least five or six years in order to pay for itself in energy terms.

Second, raw material costs: several hundred extra $\mathrm{kg}$ of assorted metals and a similar amount of glass may seem rather a high price to pay for "free heat". There is no way in which the sun can pay off the costs. Third, financial costs: because the suppliers of components were extremely generous, the final cost of the installation, at about $£ 1,200$ (at 1974-75 prices) can be described as a bargain. We must clearly wait rather more than 5-6 years for the sun to pay that off for us.

I present these points for interested readers to ponder. But as one who hates waste, I must say that when the sun comes out and I hear the switches go on, I get a warm glow.

\section{J. B. WRIGHT}

Department of Earth Sciences,

\section{Open University, UK}

\section{Birds on the Chagos Bank}

Sir,--We share the concern expressed by Messrs. Hirons, Bellamy and Shepherd (Nature, 260,$387 ; 1976$ ) for conservation in the Chagos archipelago, but we should like to comment on their proposal to exterminate the rats there. The fourteen islets on the western edge of the Chagos bank are only a fraction of over sixty in the whole Chagos archipelago, and over six hundred in the whole Indian Ocean, considered worthy of assessment for conservation by the International Union for the Conservation of Nature (Elliott, H.F.I, J. mar. biol. Ass. India, 14, 578-608; 1974). Many of these are of more scientific importance and more seriously threatened. Before scarce resources are devoted to an attempt to eliminate rats from the two largest of the western Chagos islands-something which is likely to be difficult and costly and has rarely been accomplished even on much smaller and more accessible islets elsewhere-perhaps the need requires to be demonstrated more clearly than has yet been the case in Dr Bellamy's television film about his previous expeditions.

From the information available so far (Bourne, W.R.P., Atoll Res. Bull., $149,175-207 ; 1971$ ), there appears to be nothing particularly unusual about the islands in question. While there has been a previous report that Abbott's Booby Sula abbotti has been seen at sea in the area, there is an immature plumage of the Masked Booby Sula dactylatra which strongly resembles that of adult Abbott's Boobies, and it would be helpful if more details of the birds seen could be provided to confirm their identity. If Abbott's Booby were found nesting in the group, this could be of crucial importance for the species, which is now reduced to about 2,000 pairs threatened by phosphate mining on Christmas Island (Nelson, J.B., J. mar. biol. Ass. India, 14, 643$662 ; 1974)$. On the other hand, although rats have reached Christmas Island they have not harmed the treenesting boobies there yet, although the birds might be more vulnerable in the lower vegetation of the Chagos group. The case for regarding the western Chagos islands as a potential refuge for this remarkable booby has still to be proved.

The other seabirds frequenting the Chagos group are all widespread species. Despite statements in the film that the Masked Boobies show unusual features, the specimen from the Chagos group deposited in the British Museum (Natural History) appears to us to fall within the normal range of variation for the western Indian Ocean. Together with the smaller seabirds its numbers seem more likely to be limited by conditions at sea than on land, and it seems likely the birds can still find ample breeding-sites on the undisturbed, rat-free outer islets, while the few landbirds now present in the archipelago appear to be introduced. It therefore seems questionable whether the rats are causing any more harm to the birds than to the vegetation.

While we yield to nobody in our concern at the harm caused by introduced mammals on islands (Bourne, W.R.P., New Scientist, 67, 422-425; 1975), we feel that it might be more useful if before they try to exterminate the rats Dr Bellamy and his colleagues were to dispose of the donkeys left on Diego Garcia, Ile du Coin and Ile Boddam elsewhere in the Chagos group at the time of their enforced evacuation in the early 1970s (Curtis, W.F., Sea Swallow, 25, 11-13; 1976). These seem likely to present a really serious threat to the regenerating natural vegetation if they are left to increase. It would also be interesting to know what arrangements our authorities have made to maintain continuing scientific surveillance of these potentially important nature reserves now that they have evicted their human inhabitants.

Milltimber, Aberdeen W. R. P. Bourne

J. B. Nelson

University of Aberdeen, Scotland 